(C) Ян Ян, 2019 p.

https://orcid.org/0000-0001-9791-1553

DOI: $10.34142 / 23128046.2019 .47 .19$

\title{
ВИЗНАЧЕННЯ ПОНЯТТЯ «ПЕДАГОГІЧНА ПІДТРИМКА» В УКРАЇНСЬКІЙ ТА КИТАЙСЬКІЙ НАУКОВІЙ ЛІТЕРАТУРІ
}

У публікачії визначено, щңо в умовах гуманізачії і демократизачії вищої освіти відбувається переорієнтація освітнього процесу на підготовку майбутніх фахівиів, які характеризуються не тільки сформованістю професійної компетентності, але й здатності до критичного мислення $\check{u}$ автономної діяльності. У свою чергу, ие передбачає надання педагогічної підтримки в особистісно-професійному становленні майбутнього професіонала. Тому забезпечення зазначеної підтримки для кожного суб'єкта навчання є актуальною проблемою для педагогічної теорії та практики в різних краӥнах, у тому числі в Украӥні та КНР. Мета статті на основі зіставлення точок зору украйнських та китайських учених уточнити суть поняття «педагогічна підтримка». Для реалізації визначеної мети використовувались такі теоретичні методи дослідження, як: аналіз наукових джерел, що розкривають суть досліджуваної проблеми; синтез, порівняння, систематизація наукових поглядів учених щодо визначення суті педагогічної підтримки.

На основі аналізу наукової літератури встановлено, щзо поняття «педагогічна підтримка» трактується вченими неоднозначно, зокрема як: иілеспрямована діяльність педагога, спрямована на надання оперативної або превентивної допомоги особистості в процесі ї̈ навчання та розвитку; діяльність педагога, що реалізується за такими напрямами: забезпечення внутрішніх умов (потреб, установок, потреб, здібностей) для розвитку й саморозвитку кожної особистості; створення сприятливих зовнішніх умов для існування, навчання й розвитку особистості; побудова гуманістичного мікросочіального середовища в закладі освіти через забезпечення сприятливого психологічного клімату, активної взаємодї між учасниками освітнього проиесу; залучення суб'єктів взаємодії до виконання творчої діяльності тощя. У дослідженні під педагогічною підтримкою розуміється иілеспрямована діяльність педагога, спрямована на надання допомоги особистості в процесі навчання й розвитку, стимулювання перетворення ї̈ 8 активного суб'єкта власного професійно-особистісного становлення. Також з'ясовано, щзо надання грамотної педагогічної підтримки дає змогу значно підвищити ефективність освітнього процесу у вищій школі.

Ключові слова: педагогічна підтримка, визначення, наукова література, КНР, Украӥна. 
Yang Yang. The definition of the concept of "pedagogical support" in ukrainian and chinese scientific literature. It was defined in the publication that in the context of humanization and democratization of higher education happens the reorientation of the educational process to the preparation of future professionals, that are characterized not only by the formation of professional competence, but also by the ability to think critically and autonomously. In turn, this provides the granting of a pedagogical support to the future professional in personal and professional formation. Therefore, the providing of this noted support to each subject is a pressing issue for the pedagogical theory and practice in different countries, including Ukraine and the People's Republic of China. The purpose of the article is to clarify the essence of the concept of "a pedagogical support" on the basis of the analysis of the comparison of the perspectives of Ukrainian and Chinese scholars. The following theoretical research methods were used to achieve this goal: the analysis of scientific sources that reveal the essence of the problem under study; synthesis, comparison, systematization of scientific views of scientists in determining the essence of pedagogical support.

Based on the analysis of the scientific literature, it has been established, that the concept of a pedagogical support is interpreted by the scientists ambiguously, in particular as: a purposeful activity of the teacher aimed at providing prompt or preventive assistance to the individual in the process of his / her learning and development; the activity of the teacher, that is implemented in the following areas: the providing of internal conditions (needs, attitudes, needs, abilities) for the development and self-development of each personality; the creation of favorable external conditions for its existence, training and personal development; building a humanistic micro social environment in the educational establishment by the providing a favorable psychological climate, active interaction between the participants of the educational process, involving the subjects of interaction in the performance of creative activities, etc. It was determined that the research under the pedagogical support refers to a purposeful activity of the teacher, aimed at assisting the individual in the process of its learning and development, stimulating its transformation into an active subject of their own professional and personal formation. It has also been found that providing pedagogically literate a pedagogical support can significantly improve the efficiency of the educational process in higher education.

Keywords: pedagogical support, definitions, scientific literature, China, Ukraine.

Вступ. У сучасних умовах глобалізації суспільства спостерігаються загальні для більшості країн тенденції щодо гуманізації й демократизації вищої освіти. Ці тенденції поширюються і на теренах України й КНР, вимагаючи переорієнтації освітнього процесу на підготовку майбутніх фахівців, які характеризуються не тільки високим рівнем сформованості професійної компетентності, але й наявністю здатності до критичного 
мислення й автономної діяльності. Одним із ефективних шляхів забезпечення підготовки таких фахівців $є$ розробка й реалізація на практиці індивідуальної освітньої траєкторії для кожного з них. У свою чергу, це передбачає надання педагогічної підтримки в особистісно-професійному становленні майбутнього професіонала. Тому забезпечення зазначеної підтримки для кожного суб'єкта навчання є актуальною проблемою для педагогічної теорії та практики.

Як свідчить аналіз наукової літератури, окремі аспекти зазначеної проблеми вже вивчалися науковцями. Так, витоки ідеї про важливість педагогічної підтримки людині, яка навчається, висвітлено в працях відомих європейських педагогів минулих часів - Я. Коменського, П. Наторпа, М. Монтессорі, Ф. Фребеля та ін. Теоретичні основи здійснення педагогом підтримки суб'єктів освітнього процесу розкрито в працях таких українських та китайських авторів, як Вей Хун, В. Сухомлинський, А. Бойко, І. Бех, I. Зязюн, О. Савченко, Яо Лімін та ін. Суть, структура та зміст підтримки як педагогічного феномену визначено в теоретичних доробках Є. Бондаревської, І. Зимньої, І. Карапузової, Н. Крилової, Л. Петровської, М. Риженко, Чжао Джулан, Шень Цзілян та ін. Воднораз вивчення стану теоретичної та практичної розробленості проблеми педагогічної підтримки дозволяє зробити висновок про доцільність іiі подальшого дослідження. Зокрема, існує потреба в зіставленні визначень самого поняття «педагогічна підтримка» провідними вченими України та КНР.

Мета та завдання. Мета статmі - на основі зіставлення точок зору українських та китайських учених уточнити суть поняття «педагогічна підтримка».

Методи дослідження. Для реалізації визначеної мети використовувались такі теоретичні методи дослідження, як: аналіз наукових джерел, які розкривають досліджувану проблему; синтез, порівняння, систематизація наукових поглядів учених щодо визначення суті педагогічної підтримки.

Результати. Як визначено в дослідженні, у різних країнах світу використовують терміни, які за своїм змістом є близькими до поняття «педагогічна підтримка». Наприклад, американські фахівці застосовують термін «quidance», що походить від слова «quide» - спрямовувати, вести. Цим словом вони позначають процес надання людині допомоги в складних для неї ситуаціях вибору, умовах адаптації до нових умов життєдіяльності. У Німеччині й Англії вчені суть феномену педагогічної підтримки відображають через застосовування таких понять, як pastor care (пасторська турбота, відповідальність), tutoring (опікун) тощо (Ryzhenko, 2014). Зокрема, 
британська дослідниця Дж. Фрімен у своїх публікаціях розглядає підтримку як процес втручання педагога в освітній процес суб'єкта навчання 3 метою забезпечення його пристосованості до наявних життєвих обставин та готовності впоратися з труднощами, що виникають. При цьому науковець для визначення феномену підтримки використовує термін «provision», що має на увазі не тільки надання психологічної й моральної підтримки особистості, але й навчальні програми, правові акти чи будь-які інші форми допомоги, які може отримати людина від відповідних інститутів (Freeman, 2002).

Доцільно наголосити на тому, що в українській науковій літературі поняття «педагогічна підтримка» почали використовувати після опублікування праць О. Газмана, який визначав суть цієї підтримки як професійну діяльність педагогів, спрямовану на надання допомоги суб'єктам навчання, які нездатні самостійно виконати поставлені завдання. Цей учений стверджував, що традиційна модель навчання вже застаріла, тому існує актуальна потреба в iï докорінній модернізації. У світлі цього О. Газман відстоював ідею про необхідність розвитку кожної молодої особистості через накопичення нею власного життєвого досвіду. При цьому забезпечення індивідуалізації ii навчання, за висновками вченого, відбувається через надання педагогом допомоги в побудові молодою людиною власного автономного внутрішнього світу, забезпечення усвідомлення своєї унікальності як індивідуальності, своїх основних достоїнств та недоліків, формування готовності до самостійного вибору, відпрацювання сенсу власної життєдіяльності. На підставі цього дослідник уточнював, що надання педагогічної підтримки суб'єктам навчання передбачає створення оптимальних умов для саморозвитку й самоосвіти кожної особистості, визначення iї індивідуальних цілей, інтересів, потреб, прагнень, для виявлення оптимальних способів подолання проблем, труднощів, перешкод, що виникають перед нею в освітньому процесі та взагалі в житті, сприяння індивідуальному розвитку індивіда на основі врахування як вже накопиченого ним досвіду, так і наявних у нього потенційних можливостей особистісного становлення (Gazman, 1995, 2003).

О. Газман також стверджував, що надання педагогічної підтримки суб'єктам навчання відбувається шляхом реалізації трьох напрямів педагогічної діяльності, а саме: стимулювання саморозвитку особистості на основі здійснення нею самопізнання й рефлексії, формування в молоді відповідних установок, здібностей та потреб; створення комфортних умов для розвитку й навчання кожного суб'єкта цього процесу; організації доброзичливої атмосфери в аудиторії, сприятливого психологічного клімату, 
що є необхідною передумовою успішності педагогічного впливу (Gazman, 2003).

Як з'ясовано на основі аналізу сучасної наукової літератури, учені висловлюють сьогодні різні точки зору щодо визначення суті педагогічної підтримки. Так, М. Риженко у своєму дисертаційному дослідженні відзначає, що педагогічна підтримка - це цілеспрямована діяльність педагога, спрямована на надання оперативної або превентивної допомоги особистості в процесі iї навчання та розвитку. При цьому грамотне забезпечення педагогічної підтримки стимулює розвиток та формування особистісних якостей суб’єкта педагогічної взаємодії, допомагає йому в задоволенні індивідуальних потреб, які він не може задовольнити без сторонньої допомоги (Ryzhenko, 2014).

M. Єрхова під педагогічною підтримкою розуміє діяльність, що забезпечує: розвиток суб’єктної позиції учасників освітнього процесу; гуманістичну стратегію професійної поведінки педагога; надання допомоги учаснику педагогічної взаємодії в подоланні його проблем (Yerkhova, 2002). За поглядами М. Тарасова, педагогічна підтримка - це гуманістично орієнтована взаємодія педагога 3 іншими ii учасниками, спрямована на розвиток у них пізнавальних процесів, здатності здійснювати самооцінку та самоаналіз власної діяльності, вдосконалення навичок спілкування, взаємодії з іншими людьми (Erhova, 2002).

Н. Колосова описує педагогічну підтримку як діяльність педагога, що реалізується за такими напрямами: 1) забезпечення внутрішніх умов (потреб, установок, потреб, здібностей) для розвитку й саморозвитку кожної особистості; 2) створення сприятливих зовнішніх умов для ㄲï існування, навчання й розвитку дитини; 3) побудова гуманістичного мікросоціального середовища в закладі освіти через забезпечення сприятливого психологічного клімату, здійснення активної взаємодії між учасниками освітнього процесу, залучення суб’єктів взаємодії до виконання творчої діяльності (Kolosova, 2013).

Н. Крилова у своїх наукових працях зазначає, що поняття педагогічна підтримка може використовуватись у різних значеннях, зокрема як: засіб ініціації власних сил розвитку людини, що заохочує їі до самостійного пошуку варіантів вирішення існуючих проблем, прояву відповідальності під час вибору певних дій у різних життєвих ситуаціях, а також активізує процес подальшого саморозвитку; педагогічна теорія 3 належним теоретичним обгрунтуванням та методичним забезпеченням, що спрямована на створення в закладі освіти середовища, яке сприяє особистісному росту кожного учасника навчання та становлення його як активного суб'єкта власної 
життєдіяльності; засіб індивідуалізації освітнього процесу, що допомагає перетворити його в механізм активної соціалізації молодої особистості; важливий складник освітньої політики, що сприяє підвищенню рівня успішності суб'єктів освітнього процесу шляхом забезпечення кращого усвідомлення кожним із них вимог та змісту чинних стандартів освіти (Krilova, 2000).

Як свідчить аналіз наукових праць китайських авторів (Вей Хун, Кен Бейн, Чжао Джулан, Шень Цзілян, Яо Лімін) проблема надання педагогічної підтримки учасникам освітнього процесу теж знаходиться в центрі уваги багатьох дослідників. Зокрема, названі автори відзначають, що педагогічно грамотне надання підтримки студентів у процесі навчання передбачає: 1) ретельне планування навчальної діяльності студентів із урахуванням змісту професійної підготовки та вимог до фахівця, ефективне управління цією діяльністю, надання допомоги кожному майбутньому фахівцю у виборі навчальних курсів (зокрема, студенти мають бути ознайомлені з навчальними програмами, загальними цілями освіти та конкретними цілями вивчення кожного курсу та його структурних блоків, вимогами до засвоєння курсу, формами та термінами перевірки рівня опанування навчального матеріалу тощо); 2) створення освітнього середовища, що сприяє розвитку у студентів аналітичного та критичного мислення, дає змогу чітко визначити перспективи свого подальшого професійно-особистісного розвитку; 3) збільшення часу на самостійну, дослідницьку, самоосвітню діяльність студентів, коли викладач виконує функції консультанта та модератора, що сприяє збагаченню життєвого, освітнього та професійного досвіду людини, заохочує iі до оволодіння інноваціями; 4) розвиток інноваційного мислення майбутніх фахівців, формування в них самоосвітніх умінь, переорієнтації кожного студента 3 ролі отримувача професійно необхідних знань на роль активного суб’єкта власного професійного становлення; 5) активне впровадження в освітній процес різних моделей інноваційного, кооперативного й міждисциплінарного викладання, сучасних комп'ютерних технологій та засобів; 6) надання педагогом допомоги у виробленні й реалізації на практиці індивідуальної освітньої траєкторії для кожного студента на основі врахування його індивідуальних потреб, інтересів, навчальних можливостей, рівня успішності, а це, у свою чергу, сприяє підвищенню його навчальної успішності, зростанню в людині самооцінки, віри у власні сили (Concept and mindset of effective teaching and learning management at Universities, 2010; Study of the characteristics of effective learning at Universities, 2001; The analysis of characteristics of effective teaching by college teachers, 2002; How to become a competent lecturer at University, 2007). 
Обговорення. Як визначено за результатами проведеного дослідження, поняття «педагогічна підтримка» тлумачиться китайськими та українськими вченими неоднозначно. Проте всі автори відзначають, що педагогічна підтримка передбачає стимулювання розвитку особистісних якостей людини, створення сприятливих умов для iї навчання й саморозвитку, здійснення допомоги в самостійному вирішенні поставлених завдань. Також з'ясовано, що надання педагогічно грамотної підтримки дає змогу значно підвищити ефективність освітнього процесу у вищій школі. Тому кожний педагог має приділяти значну увагу цьому аспекту у своїй професійній діяльності.

Висновки. На основі врахування тлумачень зазначеного поняття різними вченими зроблено висновок про те, що педагогічна підтримка - це цілеспрямована діяльність педагога, спрямована на надання допомоги особистості в процесі іiі навчання й розвитку, перетворення iï в активного суб'єкта власного професійно-особистісного становлення. У подальшому дослідженні планується дослідити проблему надання педагогічної підтримки професійно-особистісної самореалізації майбутнього вчителя музики.

\section{ЛІТЕРАТУРА:}

Газман О. С. Личность - субъект свободной деятельности. Новые иченности образования. M., 1995.

Газман О. С. Теория: что такое педагогическая поддержка. Классный руководитель. № 3. 2003. C. 6-33.

Ерхова М. В. Помогающее поведение учителя как средство педагогической поддержки : автореф. дис. ... канд. пед. наук : 13.00.01. Ульяновск, 2002. 20 с.

Колосова Н. Н. Педагогічна підтримка як засіб гуманізації освітнього простору дошкільного навчального закладу. Психолого-педагогічні проблеми сільської школи. 2013. № 44. С. 156-161.

Крилова Н.Б. Культурология образования. М., 2000. 272 с.

Риженко М. В. Педагогічна підтримка розвитку лідерського потенціалу старших підлітків у колективній діяльності : дис. канд. пед. наук : 13.00.07. Харків, 2014. 224 с.

Тарасов М. А. Педагогическая поддержка развития способности к личностной саморегуляции у старших дошкольников в условиях детского сада : автореф. дис. ... канд. пед. наук : 13.00.01. Хабаровск, 2006. 23 с.

Freeman, J. (2002) Out-of-school educational provision for the gifted and talented around the world. A report for the DfES. Part two: the conclusions. Retrieved from: http://www.joanfreeman.com/pdf/Text_part_two.pdf.

姚利民. 大学有效教学特征之研究 [J]. 现代大学教育. 2001(4) : 42-44.

肯.贝恩. 如何成为卓越的大学教师 $[\mathrm{M}]$. 北京 : 北京大学. 出版社, 2007.

赵菊珊. 大学有效教学及教学管理的理念与思考. 中国大学教学 2010 年第 1 期: 23-25.

魏 红, 申继亮. 高校教师有效教学的特征分析 $[\mathrm{J}]$. 西南. 师范大学学报 (人文社会科学版). 2002 (2) : 33-36.

\section{REFERENCES:}


Gazman, O. S. (1995). Lichnost' - sub\#ekt svobodnoj dejatel'nosti. [Personality is a subject of free activity]. Novye cennosti obrazovanija. Moskva (in Russian).

Gazman, O. S. (2003). Teorija: chto takoe pedagogicheskaja podderzhka. [Theory: what is a pedagogical support]. Klassnyj rukovoditel'. 3. S. 6-33. (in Russian).

Erhova, M. V. (2002). Pomogajushhee povedenie uchitelja kak sredstvo pedagogicheskoj podderzhki. [Helping teacher's behavior as a means of a pedagogical support]. (Abstract of candidate's thesis). Ul'janovsk, Rossija (in Russian).

Kolosova, N. N. (2013). Pedahohichna pidtrymka yak zasib humanizatsii osvitnoho prostoru doshkilnoho navchalnoho zakladu [Pedagogical support as a means of humanizing the educational space of a preschool institution]. Psykholoho-pedahohichni problemy silskoi shkoly. 44. S. 156-161. (in Ukrainian)

Krilova, N. B. Kul'turologija obrazovanija. [Cultural studies of science education]. Moskva (in Russian)/

Ryzhenko, M. V. (2014). Pedahohichna pidtrymka rozvytku liderskoho potentsialu starshykh pidlitkiv u kolektyvnii diialnosti [Pedagogical support for the development of leadership potential of older adolescents in collective activity]. (Candidate's thesis). Kharkiv, Ukraina (in Ukrainian).

Tarasov, M. A. Pedagogicheskaja podderzhka razvitija sposobnosti k lichnostnoj samoreguljacii $\mathrm{u}$ starshih doshkol'nikov $\mathrm{v}$ uslovijah detskogo sada. [Pedagogical support for the development of a personal self-regulation ability at senior preschool children in the infant school's conditions]. (Abstract of candidate's thesis). Habarovsk, Rossija (in Russian).

Freeman, J. (2002) Out-of-school educational provision for the gifted and talented around the world. A report for the DfES. Part two: the conclusions. Retrieved from: http://www.joanfreeman.com/pdf/Text_part_two.pdf.

姚利民. 大学有效教学特征之研究 $[\mathrm{J}]$. [Study of the characteristics of effective learning at Universities]. 现代大学教育. 2001(4)：42-44. (in Chinese)

肯. 贝恩. 如何成为卓越的大学教师 $[\mathrm{M}$ ] [How to become a competent lecturer at University]. 北京：北京大学. 出版社, 2007. (in Chinese)

赵菊珊. 大学有效教学及教学管理的理念与思考 [Concept and mindset of effective teaching and learning management at Universities]. 中国大学教学 2010 年第 1 期: 23-25. (in Chinese)

魏 红, 申继亮. 高校教师有效教学的特征分析 $[\mathrm{J}]$ [The analysis of characteristics of effective teaching by college teachers]. 西南. 师范大学学报(人文社会科学版). 2002 (2) : 33-36. (in Chinese)

\section{Ян Ян}

\section{Інформація про автора:}

ORCID: https://0000-0001-9791-1553; аспірант кафедри загальної педагогіки і педагогіки вищої школи Харківського національного педагогічного університету імені Г.С. Сковороди, вул. Валентинівська, 2, м. Харків, Україна, 61000.

e-mail: macqihui@qq.com

\section{Information about the author:} Yang Yang ORCID: $\quad$ https://0000-0001-9791-1553; doctoral PhD Student of the Department of General Pedagogy Department and the Pedagogy of Higher School of H. S. Skovoroda Kharkiv National Pedagogical University, Valentynivska street, 2, Kharkiv, Ukraine 61000.

e-mail: macqihui@qq.com 
Цитуйте цю статтю як: Ян Ян. Визначення поняття «педагогічна підтримка» в українській та китайській науковій літературі. Теорія та методика навчання та виховання. 2019. № 47. С.211-219.

DOI: $10.34142 / 23128046.2019 .47 .19$

Дата надходження статті до редакції: 22.11.2019

Стаття прийнята до друку: 03.12.2019 